\title{
Soymilk Formula Increases Estrogen and Reduces Testosterone Level in Male Infant White Wistar Rats
}

\author{
Eveline Margo', Wimpie Pangkahila², I Gusti Made Aman³ \\ ${ }^{1}$ Department of Phisiology, Faculty of Medicine, Trisakti University, Jakarta, Indonesia \\ ${ }^{2}$ Department of Andrology and Sexology, Faculty of Medicine, Udayana University, Denpasar, Bali, Indonesia \\ ${ }^{3}$ Department of Pharmacology, Faculty of Medicine, Udayana University, Denpasar, Bali, Indonesia
}

Background: Children's immunity system is relatively lower on first year of life, causing atopic babies, leading to allergy. Ideally, newborn babies are given breast milk as main food source on the first 6 months, but often being replaced with cow milk which can induce Cow's Milk Protein Allergy. For the alternative can replace it with soymilk formula which contains phytoestrogen from isoflavon, which works just like estrogen. The aim of this study to determine whether administration of soymilk formula is capable on increasing estrogen level and reducing testosterone level on male infant white Wistar rats (Rattus norvegicus).

Materials and Methods: This research used post test only control group design. Samples were consisted of 36 infant male white Wistar rats aged 7 days, weighing from 10-15 grams, divided into 2 groups, control group which was given cow's milk and intervention group which was given soymilk. Each group were given intervention with the dose $5 \%$ of BW (grams), given twice-a-day orally for 21 days, and subsequently in the morning their blood samples were taken to examine the level of estrogen and testosterone hormone.

Results: The study showed that the level of estrogen on intervention group was significantly higher than the control group with mean estrogen level of $0.55 \pm 0.03 \mathrm{pg} / \mathrm{mL}$ in the control group and $0.82 \pm 0.01 \mathrm{pg} / \mathrm{mL}$ in the intervention group, while the mean testosterone level was significantly lower on intervention group compared with control group $(p<0.05)$ with $3.25 \pm 0.15 \mathrm{ng} / \mathrm{mL}$ on control group and $2.36 \pm 0.22 \mathrm{ng} / \mathrm{mL}$ on intervention group.

Conclusion: Soymilk was able to increase estrogen level and reduce testosterone level on male infant white Wistar rats (Rattus norvegicus).

Keywords: soymilk formula, estrogen, testosterone, male infant rats

\section{Introduction}

Food allergy is an increasing health care concern. Food allergy is defined as an adverse health effect arising from a spesific immune response that occurs because exposure to a givenfood. The main foreign protein introduced to the babies are cow's milk protein, frequently causing cow's milk protein allergy (CMPA) on babies who having atopic

Date of submission: October 11, 2018

Last Revised: November 7, 2018

Accepted for publication: November 9, 2018

Corresponding Author:

Eveline Margo

Department of Phisiology

Faculty of Medicine, Universitas Trisakti

J. Kyai Tapa No. 260, Jakarta 11440, Indonesia

E-mail: eveline_margo@yahoo.com

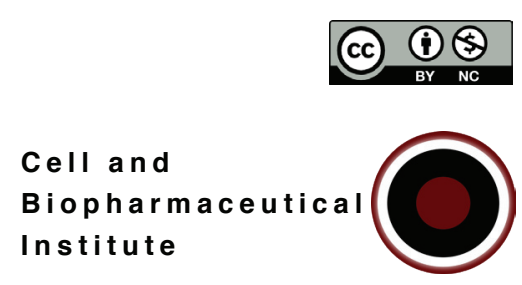


trait. CMPA does seem to peak in the first year of life, with a incidence of CMPA approximately $2-3 \%$ in the infant population. This incidence then falls to $<1 \%$ in children 6 years of age and older. ${ }^{1}$ About $30-45 \%$ of all babies aged 1 year with atopic dermatitis are caused by CMPA. One of the treatments for this is by replacing the milk with soymilk formula which is administered until tolerance against cow's milk is reached. ${ }^{2,3}$

Soya bean (glycine max) is a member of Leguminosae family (beans) containing phytoestrogen from isoflavones class. Isoflavones has chemical structure similar to estrogen. The phenolic ring on isoflavones binds with estrogen receptor (ER), mimicking the work of estrogen causing the same effects as estrogen (agonist) or antagonist. The activity of isoflavones depends on the concentration of endogenous estradiol. In the environment with low estrogen level, isoflavones works as estrogen agonist, while in the environment with high estradiol level, isoflavones acts as estrogen antagonist (estrogen activity inhibitor). ${ }^{1,4}$

In addition to the binding of ER, genistein showed binding activity to sex hormone-binding globulin (SHBG) relative to estradiol. The binding with SHBG may transport genistein into plasma and increase the concentrations of unbound estradiol. ${ }^{5}$

Soymilk formula is a milk using soybean protein isolates as basic material. Babies consuming soymilk formula has a high serum isoflavones level. Soymilk formula contains phytoestrogen from isoflavones class with potential activity similar to estrogen hormone, because of the phenolic ring which is able to bind with ER. ${ }^{6}$

Adults rarely obtained more than $25 \%$ of daily calories from soy protein, while babies using soy obtained $100 \%$ of the calories solely from soy. In babies daily intake of soymilk formula is approximately $4 \mathrm{mg} / \mathrm{kgBW}-11 \mathrm{mg} / \mathrm{kgBW}$. The average administration of soymilk formula in children is the same as the amount of soy based food consumed by adults, but the concentration of isoflavones in plasma is higher on babies compared to the adults. Clinical data mentioned that $0-3 \%$ phytoestrogen in the blood plasma of babies consuming soymilk formula is in their active state. ${ }^{7,8}$

Although soy isoflavones have a weak estrogenic effects, about $10^{2}-10^{3}$ times less potent than endogenous estrogen, but infants who consume soymilk formula have high levels of serum isoflavones. Total isoflavone concentration of soymilk formula for infants was around $32-47 \mathrm{mg} / \mathrm{L}$, while in breast milk were only an averange of $5.6 \mu \mathrm{g} / \mathrm{L}$. Because of that, infants who are given soymilk formula are exposed $5.7-11.9 \mathrm{mg}$ isoflavones $/ \mathrm{kgBW}$ or 22-45 mg isoflavones per day for the first 4 months, while those given breast milk can be ignored, around $<0.01$ $\mathrm{mg} / \mathrm{L}$. If compared to adults who consumed soy-rich food with an amount about $0.71 \mathrm{mg} / \mathrm{kgBW}$, then infants fed soymilk formula are exposed 6-11 times higher. Isoflavone concentrations in blood plasma about $654-1775 \mu \mathrm{g} / \mathrm{L}$ for 4 months infants with soymilk formula, more higher than those who given breast milk or cow's milk formula. ${ }^{7,9}$

Isoflavones concentration circulating inside babies' body given with soy milk formula is 13.000-22.000 times higher than the level of $17-\beta$-estradiol in the blood circulation in the early stage of life, but this cannot give a clear picture of babies' estrogen status. ${ }^{6}$ Isoflavones on soymilk formula is relatively weak estrogen, but the amount is substantial. Therefore, there is a growing concern that isoflavones can mimic the acts of estradiol or change the metabolism of estradiol, causing modification of processes affected by estradiol. ${ }^{7,9}$

The isoflavones can mimic estradiol or alter estradiol and consequently modify processes that are affected by estradiol, such as affecting the reproductive, immune and tiroid system. Hormonal changes especially during the fetus will cause reproductive abnormalities such as decreased sperm count, testicular germ cell cancer, cryptorchidism, and hypospadias. ${ }^{10}$

The study conducted in Iowa where compared puberty maturation, menstruation and reproductive history in participants from age 20-34 years who was given soymilk and cow's milk formula, it was found that in the soymilk group the duration of menstruation was longer and had discomfort and pain during menstruation. ${ }^{11}$ This result also same to the study that conducted by Adgent in UK, the girls who drank soymilk formula get menarche earlier. ${ }^{9}$ The study by Bernbaum, et al., by giving soymilk formula to 6 months old baby girls reported an increase maturation of vaginal cells as an effect of estrogenic. ${ }^{6}$

In the study of aromatase knockout in male rats, the result is unable to synthesize endogenous estrogens, then were given isoflavones found no abnormalities in spermatogenesis in the group that given isoflavones compared with those which not given intake. ${ }^{12}$ But, in other study using male baby rats found inconsistent results in serum FSH, LH and testosterone. ${ }^{6}$

Until now there is still debate over whether there should be warning about the use of soymilk formula for infants. In developed countries such as Canada, USA and UK, the 
use of soy formula can only be used with consideration of health, cultural and religious reasons, even in European countries can only be obtained with the approval and under supervision of doctors. ${ }^{6}$

It is important to know when the exposure time has an effect on health and how long the exposure can effect the development of body organs, especially in the development of the reproductive organs. ${ }^{6}$

Based on these, this study want to know whether administration of soymilk formula will increases estrogen and reduces testosterone levels on male infant white Wistar rats (Rattus norvegicus).

\section{Materials and methods}

This study has passed the Commission for Medical Research Ethics, Faculty of Medicine, Udayana University, Denpasar, Bali with ethical approval number 668.02.1.2014. This study is an experimental research using post test only control group design conducted in Laboratory Animal Unit from November 22, 2015 until February 6, 2016.

The sample consisted of 36 healthy male white (not albino) infant Wistar rats aged 7 days, weighing from 10-15 grams, divided into two groups randomly, control group which is given cow's milk formula for babies aged 0-6 months and intervention group which will be given soymilk formula for babies 0-6 months, and each groups's intervention has a dose of $5 \% \mathrm{BW}(\mathrm{gr})$. The formula diluted with 2 times the recommended water and feeded by syringe 24 gauge. ${ }^{13}$ Administration was done twice a day orally for 21 days (in accordance with breastfeeding period). ${ }^{14}$ After the intervention, blood sample as much as $0.5 \mathrm{cc}$ from the baby rats were taken in medial canthus sinus orbitalis of right eye, conducted in the morning to check the level of estrogen and testosterone. Examination level of estrogen and testosterone by used ELISA methods. ${ }^{11}$ Hormone level examination was conducted in UPT (Comprehensive Service Unit) Analytic Laboratory University of Udayana, Jimbaran Hill College.
The collected data were processed with the SPSS program version 16.0. The data were evaluated for normality by means of Shapiro-Wilk test. Since the data in this study were normally distributed, comparison between two groups was done by t-independent test, while the Levene's test was used to evaluate the variance. The level of significance was set at 0.05 .

\section{Results}

Analysis of treatment effect using t-independent test from estrogen mean between groups after treatment of either cow's milk or soymilk formula is shown in this Table 1. Based on Table 1, it is shown that the estrogen mean of control group is $0.55 \pm 0.03$ and the mean in treatment group is $0.82 \pm 0.01$. Significancy test with t-independent test showed that $p$-value 0.001 . This means that estrogen mean in both groups after administration of treatment is significantly different.

Treatment effect analysis was tested based on testosterone mean between groups after administration of treatment cow's milk or soymilk formula. The significancy analysis with t-independent is shown in Table 1. Based on Table 1, it is shown that the testosterone mean of control group is $3.25 \pm 0.15$ and the mean in treatment group is $2.36 \pm 0.22$. Significancy test with t-independent test showed that $p$-value 0.001 . This means that testosterone mean in both groups after administration of treatment is significantly different.

Based on result above, it's showed that in the treatment group there were an increases in estrogen amount as much as $48.09 \%$ and there were a decreases in testoterone amount as much as $27.44 \%$, compared with control group.

\section{Discussion}

The results happened because soymilk formula contains isoflavon which is a phytoestrogen compund so it has estrogen activity. Isoflavon structure is similar with

Table 1. Difference of estrogen and testosterone mean between groups after administration of cow's milk and soymilk formula.

\begin{tabular}{lccccc}
\hline Subject Group & $\mathbf{n}$ & $\begin{array}{c}\text { Estrogen }(\mathrm{pg} / \mathrm{mL}) \\
(\operatorname{mean} \pm \mathbf{S D})\end{array}$ & $\boldsymbol{p}$ & $\begin{array}{c}\text { Testosterone }(\mathrm{mg} / \mathrm{mL}) \\
(\operatorname{mean} \pm \text { SD) }\end{array}$ & $\boldsymbol{p}$ \\
\hline Control & 18 & $0.55 \pm 0.03$ & & $3.25 \pm 0.15$ & \\
Treatment & 18 & $0.82 \pm 0.01$ & 0.001 & $2.36 \pm 0.22$ & 0.001 \\
\hline
\end{tabular}


estrogen chemical structure and has a hormonal activity. Phenolic ring in isoflavones function is to bind with ER so it can produce the same effect as estrogen (agonist). Isoflavones binds with ER in hypophysis and induce the secretion of FSH and LH. LH secretion stimulate Leydig cell and germinal Cell to secrete the estrogen, causing the high level of estrogen and inducing feed back mechanism that causing the decrease in testosterone level. ${ }^{1}$

The decrease in LH secretion causing Leydig cell to increase its ability to secrete tetosterone. Testosterone undergone aromatization to become estradiol. Testosterone and estradiol together have the activity to inhibit the secretion of FSH and $\mathrm{LH}$, so the testosterone secretion decline. Beside that, testosterone precursor is cholesterol, and the disorder in LH secretion will also cause

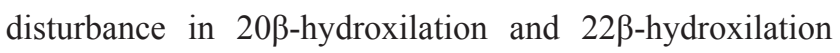
enzymes, so the fragmentation of side chain to become pregnenolone and isocaproic acid will be disturb and at last, testosterone is not formed. Isoflavones is also inhibit the $17-\beta$-hydroxysteroidoxireductase enzyme that is needed to synthesize testosterone, so even the pregnenolon is formed, it cannot been converted to testosterone. ${ }^{10}$

Decreasing testosterone level also causing the decline in aromatization of androgen to become estrogen, resulting the isoflavones work as the agonist of estrogen (estrogen like) and copying the activity of estrogen and binds with ER in epididymal, prostate, and testis tissue so it can stimulate the secretion of estrogen. The increase in estrogen amount will caused the declining in secretion of testosterone from the LH inhibition. ${ }^{4,7,15}$

This results same as the study using mature male rats which was given isoflavones isolates, there was a decrease in testosterone level, decline in testis weight, decrease in seminiferous tubulus diameter, and spermatogenesis disorders. ${ }^{6}$

\section{Conclusion}

Administration of soymilk formula (Glycine max) is capable of increasing estrogen and decreasing testosterone level in male infant white Wistar rats. Further studies are needed to confirm about about the continual effect of soymilk formula (Glycine max) to development of reproduction organ and it will give additional consideration if it is evidence in human about the administration of soymilk formula to baby, especially a boy who has CMPA.

\section{References}

1. Kim SH, Park MJ. Effects of phytoestrogen on sexual development. Korean J Pediatr. 2012; 55(8): 265-71.

2. Munasir Z, Siregar SP. Alergi susu sapi. In: Alergi-Imunologi Anak. 2nd ed. Jakarta: Badan Penerbit IDAI; 2010. p.284-93.

3. Koletzko S, Niggemann B, Arato A, Dias JA, Heuschkel R, Husby S, et al. Diagnostic approach and management of cow's milk protein allergy in infants and children: ESPGHAN GI Committee practical guidelines. J Pediatr Gastroenterol Nutr. 2012; 55(2): 221-9.

4. Chen A, Rogan WJ. Isoflavones in soy infant formula: a review of evidence for endocrine and other activity in infants. Annu Rev Nutr. 2004; 24: 33-54.

5. Cao Y, Calafat AM, Doerge DR, Umbach DM, Bernbaum JC, Twaddle NC, et al. Isoflavone in urine, saliva, and blood of infants: data from a pilot study on the estrogenic activity of soy formula. J Expo Sci Environ Epidemiol. 2009; 19(2): 223-34.

6. Dinsdale EC, Ward WE. Early Exposure to soy isoflavones and effects on reproductive health: a review of human and animal studies. Nutrients. 2010; 2(11): 1156-87.

7. Leung A, Otley A. Concerns for the use of soy-based formulas in infant nutrition. Peadiatr Child Health. 2009; 14(3): 109-13.

8. Strom BL, Schinnar R, Zieger EE, Barnhart KT, Sammel MD, et al. Exposure to soy-based formula in infancy and endocrinological and reproductive outcomes in young adulthood. JAMA. 2001; 286(7): 807-14.

9. Hughes I. Variability and Uncertainty inToxicology of Chemicals in Food, Consumer Products and the Environment. London: Committee on Toxicity of Chemicals in Food, Consumer Products and the Environment; 2007.

10. Linus Pauling Institute, Oregon State University [Internet]. Drake VJ. Isoflavones [updated 2009 Dec; cited 2015 Aug 30]. Available from: https://lpi.oregonstate.edu/mic/dietary-factors/phytochemicals/soyisoflavones.

11. Braunstein GD. Testes. In: Gardner DG, Shoback D, editors. Greenspan's: Basic \& Clinical Endocrinology. 9th ed. New York: McGraw-Hill; 2011. p.395-401.

12. Robertson KM, O'Donnell L, Simpson ER, Jones ME. The phenotype of aromatase knockout mouse reveals dietary phytoestrogens impact significantly on testis function. Endrocrinology. 2002; 143(8): 2913-21.

13. American Fancy Rat \& Mouse Association [Internet]. Robbins K. Caring for Rat \& Mouse Orphans [updated 1998; cited 2015 Oct 27]. Available from: http://www.afrma.org/orphanrm.htm.

14. Widiartini W, Siswati E, Setiyawati A, Rohmah IM, Prastyo E. Pengembangan Usaha Produksi Tikus Putih (Rattus norvegicus) Tersertifikasi Dalam Upaya Memenuhi Kebutuhan Hewan Laboratorium. e-Proceedings PIMNAS. 2013: PKM-K; 1-8.

15. Kumar R. Testis. In: Tunru ISA, editor. Dasar-dasar Patofisiologi Penyakit. Tangerang: Binarupa Aksara Publisher; 2013. p.462-8. 